International Relations

\title{
Al-Qaeda's grievances in context: reconciling sharia and society
}

\begin{tabular}{|c|c|}
\hline Journal: & International Relations \\
\hline Manuscript ID & IR-14-0067.R3 \\
\hline Manuscript Type: & Original Manuscript \\
\hline Keywords: & legal hybrids, sharia, constitutions, Egypt, Al-Qaeda, Ayman al-Zawahiri \\
\hline Abstract: & $\begin{array}{l}\text { At a time when political debate in the West is preoccupied with the } \\
\text { perceived impact of extremist ideas on individuals who embrace or support } \\
\text { terrorism, this article uses the publicly articulated grievances of Ayman al- } \\
\text { Zawahiri, Al-Qaeda's most prolific ideologue, as a case study to examine } \\
\text { how a globally focused and distributed extremist narrative matches political } \\
\text { realities on the ground. The purpose of the article is to compare two } \\
\text { political processes: the approach of Islamist extremists, as represented by } \\
\text { Zawahiri, to constitutional reform as articulated through public appeals to } \\
\text { potential supporters versus the reality of constitutional amendments and } \\
\text { evolution of fundamental law in the Middle East and South Asia. } \\
\text { Incorporating insights from studies on law and society and international } \\
\text { relations, the article demonstrates how Zawahiri's interpretation of } \\
\text { religious law emphasises wholesale adoption of sharia whilst the process of } \\
\text { legal reform has invariably resulted in the creation of legal hybrids, mixing } \\
\text { Islamic and non-Islamic legal traditions. This is not an article about } \\
\text { theology or religious law but an effort to dissect the public relations of an } \\
\text { international terrorist movement. The analysis pays particular attention to } \\
\text { events in Zawahiri's native Egypt, where evolving grievances concerning a } \\
\text { series of constitutional amendments-including those following the Arab } \\
\text { revolutions and the toppling of Mohammed Morsi-can now be assessed. }\end{array}$ \\
\hline
\end{tabular}

\section{SCHOLARONE ${ }^{\text {m }}$}

Manuscripts 


\title{
Al-Qaeda's grievances in context: reconciling sharia and society
}

\begin{abstract}
At a time when political debate in the West is preoccupied with the perceived impact of extremist ideas on individuals who embrace or support terrorism, this article uses the publicly articulated grievances of Ayman al-Zawahiri, Al-Qaeda's most prolific ideologue, as a case study to examine how a globally focused and distributed extremist narrative matches political realities on the ground. The approach of the article is to compare two political processes: the approach of Islamist extremists, as represented by Zawahiri, to constitutional reform as articulated through public appeals to potential supporters versus the reality of constitutional amendments and evolution of fundamental law in the Middle East and South Asia. Incorporating insights from studies on law and society and international relations, the article demonstrates how Zawahiri's interpretation of religious law emphasises wholesale adoption of sharia whilst the process of legal reform has invariably resulted in the creation of legal hybrids, mixing Islamic and non-Islamic legal traditions. This is not an article about theology or religious law but an effort to dissect the public relations of an international terrorist movement. The analysis pays particular attention to events in Zawahiri's native Egypt, where evolving grievances concerning a series of constitutional amendments - including those following the Arab revolutions and the toppling of Mohammed Morsi-are assessed.
\end{abstract}

\section{Key words}

Islamist extremism, constitutions, legal hybrids, sharia, Al-Qaeda, terrorism, Ayman al-Zawahiri, public relations, political rhetoric and reality, Egypt, ISIL, jihadism

\section{Introduction}

Major cataclysms of contemporary jihadism, such as the 9/11 attacks or the Islamic State of Iraq and the Levant (ISIL or Islamic State, IS) takeover of parts of Iraq and 
Syria in 2014, often provoke debates about the 'essence' of the jihadi mindset. What are they fighting for? What are they trying to achieve? Some argue 'they' - the array of Islamist extremist militants captured by the catchall term 'Salafi-jihadists' - hate the very essence of their adversary, whilst others point to tangible grievances such as Western hegemony and foreign policy. In reality, these two principal sources of grievance are intertwined: depictions of suffering and hardship are mixed with notions of illegitimacy of the current order and the need to replace it. One manifestation of this grievance narrative - and a major preoccupation of jihadi movements - is the focus on replacing colonial and positive law with religious law. This legal emphasis combines diagnosis and prognosis in the rhetoric of jihadi movements ${ }^{1}$ and is epitomised by transnational groupings such as ISIL that claim to have established and implemented (their interpretation of) Islamic governance in the territories they control.

Yet this major preoccupation of Salafi-jihadi groups often focuses on territories and regions where legislators and society have been grappling with the role of Islam and sharia for generations.

This article, in turn, compares two political processes: the 'Salafi-jihadi' approach to constitutional reform as articulated through public appeals to potential supporters versus the reality of constitutional amendments and evolution of fundamental law on the ground. My focus is on communiques delivered by Ayman alZawahiri, Usama bin Ladin's successor as leader of Al-Qaeda.

I wish to compare Zawahiri's public rhetoric against political realities whereby attempts to introduce sharia for multifaceted societies invariably result in the construction of legal hybrids. The focus of the article is on Zawahiri's native Egypt, where the Al-Qaeda leader first became involved in politics in the late 1960s and in militancy in the $1980 \mathrm{~s}^{2}$ The objective is to highlight constitutional reform-and constitutional hybrids especially — as particular grievance that is central to Zawahiri's public messages but something that is often overlooked in analyses of this discourse. The focus is less on Zawahiri himself, therefore, but rather onhis rhetorical output which can be seen as indicative of how a globally focused terrorist leader seeks to frame political events and reconcile these with existent master narratives. ${ }^{3}$ 
I want to explore this content broadly, rather than focusing on the detailed evolution of particular narrative themes. In doing so, I incorporate insights from constitutional, socio-legal and political-historical studies as well as analyses of AlQaeda and other jihadi movements. I begin by examining constitutional and sociolegal issues as part of Al-Qaeda's public narrative, introducing the concept of fundamental law in Al-Qaeda's and Zawahiri's discourse, setting out the context of this narrative: the evolution of legal-hybrids and role of sharia-based claims in AlQaeda's war of words with ISIL. I then trace the evolution of legal hybrids in Egypt and explain the substance of Zawahiri's sharia-focused retort. I conclude by discussing the significance of contrasting the substance of these public relations initiatives against the evolving political landscape on the ground. Before setting out this argument, however, it is important to clarify the meaning of key concepts and terms as they are presented in this article.

\section{What is sharia?}

Sharia has been described as 'God's eternal and immutable will for humanity', which is binding for believers. This will is expressed directly through the Quran and by Muhammad's example (Sunnah), captured in accounts of the prophet's conversations (hadith) and actions. Yet only a small proportion of Quranic verses specifically address questions of law (even though some are extensive). ${ }^{4}$ In the centuries after the formation of the first Islamic societies, therefore, professional scholar-jurists were entrusted to interpret sharia through a process of logical reasoning in order to arrive at jurisprudential edicts. ${ }^{5}$

The term sharia, therefore is often used to refer to 'the entirety of legal disciplines as developed from within the Islamic tradition', as Mallat notes, ${ }^{6}$ including decrees arrived at through human reasoning that would be seen as immutably fallible. ${ }^{7}$ Since Sunni Islam lacks a clerical hierarchy, however, such human interpretations and applications of scripture can be readily refuted and challenged. For instance, Ayman al-Zawahiri, a surgeon by training, acknowledged in an online statement published in 
September 2015, 'I love knowledge but I am by no means a scholar or an academic'. 8 Yet, as I explore below, he has frequently set out his own vision for implementing sharia through constitutional reform without elucidating in any detail how he defines the term or how he will extrapolate from scripture to judge and design contemporary society. Sharia, as this article unwraps, exists for Zawahiri as a rhetorical tool which is deployed as a sacred constant that is used to expose the illegitimacy of 'the other' and the inherent righteousness of his own political position.

\section{Al-Qaeda, the 'Salafi-jihadi' universe and beyond}

Public statements from the Al-Qaeda leaders have focused primarily on constitutional developments in Saudi Arabia, Pakistan and Egypt - countries where significant measures have been put in place to respect and adhere to Islamic legal norms. The outcome of constitutional debates in these countries, moreover, invariably results in some form of compromise in the form of legal hybrids. Such hybrids undermine the very notion of religious purity upon which Salafi-jihadi movements are based and thus become part of their grievances as regards legal and constitutional matters in Muslim-majority countries.

'Salafi-jihadi' entities, of course, do not constitute a homogenous monolith. They are a scattered, diverse and heterogeneous set of actors, united, as Wagemakers noted, in their belief 'that jihad should not just be waged against invading or aggressive non-Muslim enemies but should also be used in a revolutionary way against the 'apostate' rulers in their own midst'. 'Salafi-jihadism', therefore, is a holistic reference that, as Hegghammer argued, tells us virtually nothing about who is considered the main enemy and how he should be fought: 'the actors subsumed in this category do not share political preferences.' ${ }^{10}$ The 'Salafi-jihadi' umbrella term disguises many conflicting approaches to theology, implementation of scripture, conceptualisations of enmity, methodology and strategic prioritisation as I shall revisit below.

Before the emergence of ISIL, Al-Qaeda reigned as the most prominent global jihadist entity and its agenda has been most prolifically posited by its second commander-in-chief, Ayman al-Zawahiri. Zawahiri spent decades battling what he 
perceived as secular authoritarianism in his native Egypt before merging his flock with that of Usama bin Ladin to create 'Qaedat Al-Jihad' ('the base of jihad'). Whilst his agenda became more international, however, Zawahiri never lost sight of his native Egypt and the process - in particular - of constitutional reform. Yet these ambitions clashed with the political realities on the ground in Egypt where Zawahiri's voice has been just one of many articulating a preference for constitutional reform that reconciles the role of sharia.

Zawahiri thus competes with other actors within his milieu, such as ISIL, as well as other alternative voices, vying for the attention of the same population. The political context - often underexplored in studies of 'terrorist media'-is therefore central to and intertwined with my argument. Zawahiri's rhetoric, and that of others like him, is ultimately supposed to relate to people's daily lives and the realities they face in the communities in which they live. Developing two analytical threads that explore both the rhetoric and the reality on the ground is thus essential to understand this message in the political context for which it is designed.

The thrust of Zawahiri's focus since the dawn of the Arab uprisings in late 2010 was on the turmoil in Egypt - from revolution to government by the Muslim Brotherhood and back to secular(ish) authoritarianism - to which he has sought to respond via public media initiatives. This article presents Zawahiri as a political actor who has - albeit remotely-been involved in these debates and who has a stake in their outcome. This study is also relevant in the context of the emergence of ISIL that has challenged Zawahiri's version of Islamist-inspired militancy and transition in the region.

Why is this perspective important? As well as defeating terrorist organisations, political attention in the West has increasingly turned to challenging the ideas that are seen to underpin them. Debates about 'poisonous ideologies' 11 and how to counter them have become prominent on the international political stage. The latter task, moreover, seems harder than the former: organisations can be undermined by targeting leaders or striking at headquarters and infrastructure. But 'killing' an idea is much more difficult. An understanding of how these beliefs and ideas are constructed, therefore, and in particular how they relate to the political realities that they are 
supposed to shape becomes increasingly important for both the practitioner and student of international relations.

It is important to note, of course, that Zawahiri's contribution to these beliefs and ideas is not scholarly sophisticated, nor is it intended to be. Zawahiri's is a simple and often repetitive narrative that is supposed to appeal to the masses, rather than scholars or intellectual elites, who are usually seen as part of the problem. This narrative forms part of the Al-Qaeda leader's public relations campaign and is often presented in media initiatives that incorporate styles adopted by the mainstream press, such as interviews and written opinion pieces.

It is also important to note that the 'true' meaning of sharia and thus the essence of what constitutes a legitimate society differs according to perception and interpretation. No static meaning is universally adopted. Sharia in practice, as noted, is a system of law based on analogy and adaptation, not a defined body of edicts. As a result, allegations of improper or unrepresentative references to or applications of sharia flavour political debates and the rhetoric of extremist fringe actors. These actors seek to outbid rivals through claiming a greater degree of accuracy in their interpretation of scripture and thus a clearer sense of 'purity' in its application, analogous to the society over which the first four Caliphs of Islam presided, free of subsequent man-made modifications. Zawahiri, for example, compared the Egyptian Islamist An-Nour Party's approach to sharia to that of the Saudi royal family: Islamic law was respected on the surface whilst the real ambition was to secure political power by currying favours from America and entrench a system of patronage and corruption. ${ }^{12}$ ISIL, meanwhile, has-as I shall discuss in more detail belowpresented Zawahiri's approach to sharia as inherently misguided, to which the former has retorted with his own allegations of ISIL's sharia infringement.

\section{Constitutional and socio-legal issues as part of the Al-Qaeda public narrative}

Between April 1994 and August 1995, Usama bin Ladin, then leader of Al-Qaeda, published fourteen open letters to the political leadership of Saudi Arabia, addressing the way in which politics and society had evolved under King Fahd. The central issue for bin Ladin was the extent to which he felt the Saudi regime had paid lip service to 
the implementation of religious law and juristic protocols in favour of Western-style 'laws of positivism', which, he claimed, were in 'opposition to the will of Allah., ${ }^{13}$

It may seem strange that bin Ladin became so preoccupied with what he saw as insufficient attention to sharia implementation in a country that has otherwise become known as relying extensively on direct references to sharia (albeit in uncodified form), especially as regards criminal law. For bin Ladin, however, the principal sin of the Saudi regime was that sharia and the spirit of sharia was implemented selectively. Reliance on religious law was thus not absolute, according to bin Ladin, and much of the impact of sharia law on Saudi society was superficial, he argued. ${ }^{14}$

Notions of religious purity and prevention of any form of 'dilution' of the faith in the way society is organised and legislated are presented as stark binaries in AlQaeda's rhetoric. Dichotomies pitching virtue against vice, true believers against disbelievers and hypocrites, or the true creed against westernised rationalism and materialism are central to Salafi-jihadi rhetoric. ${ }^{15}$ This 'pure' ideal-type, meanwhile, is contrasted against efforts to introduce sharia through legal reform in Muslimmajority countries where the outcome has always been some form of legal hybrid. This outcome, in turn, feeds back into the Salafi-jihadi grievance narrative in an apparently perpetual grievance loop that is articulated to audiences and used to rationalise and promote violence.

\section{Constitutional hybridity and 'dilution' of sharia}

For years, state legislators in many Muslim-majority countries have sought to reconcile different positions regarding Islamic law by establishing what Fadel calls 'systems of legal hybridity'. ${ }^{16}$ Since independence in Egypt, for instance, legislators mixed pre-modern Islamic law with remnants of European colonial state law and positive law that sought to reconcile Islamic legal sensibilities with the modernist state project. ${ }^{17}$ With the demise of pan-Arabism in the 1970 s, many looked to Islam for solutions to the many problems affecting the region. This Islamic revivalism, according to Lombardi, 'profoundly affected constitutions in the Muslim world., 18 
This relates in particular to the introduction of what have been termed 'Sharia Guarantee Clauses' (SGCs) or 'repugnancy clauses ${ }^{19}$. Lombardi writes:

SGCs try to realize through the lens of modern constitutionalism the classical Islamic political principle that a ruler's laws should respect the fundamental principles of sharia. The SGC provides that, even if a law has been enacted according to constitutionally correct procedures, that law must be treated as void if it is inconsistent with sharia. ${ }^{20}$

The exact meaning and impact of these SGCs, however, depends on their interpretation and fundamentals of institutional design. Here, compromise between diffuse political interests and dispositions-including Islamists and secularistsbecomes key. As Stilt observes:

Once a constitution is promulgated, 'new sets of interests and expectations form around the clauses and they enter a new phase, both attached to their historical development and available to take on-and be assigned-meanings by new individual and institutional actors within that country and beyond. ${ }^{21}$

Some have pointed to the so-called 'Turkish model' as a potential template for compromise that can be adopted. This model of modern Turkey and the government of the Justice and Development Party (AK) has emerged, Choudhry argues, as 'the central example of a state that has grappled with the relationship between political Islam, political competition, and constitutionalism in the Muslim world. ${ }^{22}$ This spirit of compromise between Islamic and non-Islamic legal codes has a long tradition in Anatolia, where Ottoman expansion and consolidation of power was made easier by the Empire's willingness to tolerate different religious creeds and socio-legal norms. ${ }^{23}$ Yet such hybrids and compromises continue to constitute a major grievance for AlQaeda and other Salafi-jihadis and herein lies a central contradiction in their rhetoric.

The Al-Qaeda leadership has always been keen to celebrate the reach of Ottoman territorial expansion but ignores its legacy of compromise and reconciliation. The focus is on the re-establishment of the societal organisation apparently introduced by the Prophet Mohammed, his companions and their immediate successors as gauged primarily from hadith and biographies of the Prophet, but on a geographical scale that encompasses 'every land that was once home for Islam', seen from a contemporary perspective. This of course includes the Ottoman Empire at the height 
of its power and Muslim Al-Andalus. ${ }^{24}$ This central feature of the discourse, therefore, is a myth, an ideological construct upon which the fundamental idea of Muslim 'reconquest' is based. ${ }^{25}$

The current 'Turkish model', in short, is seen as part of the problem. The AK government and Turkish army were 'tools of the Crusade,' Zawahiri noted in one of his statements, and the country had become secular, despite the AK's Islamist credentials. ${ }^{26}$ As is often observed, the major problem is the introduction of Westernstyle liberal democracy_presented as a form of idol worship-intertwined with concepts of the modern nation state and colonial-era drafting of state boundaries.

This position has been embraced by other Islamists and impacted debates surrounding constitutional design. For example, during the formative years of Pakistan, the Jamaat-e-Islami organisation and its founder Mawlana Abul Ala Mawdudi objected to the incorporation of Western-style democratic principles into the constitution of the new Pakistani state. Pakistan had to become an Islamic state, Mawdudi insisted, and avoid legalising polytheism through adoption of pluralist legislative assemblies. Legislation, according to Mawdudi, ought to rest solely on the Quran and Sunnah, which would be interpreted and applied by an elected head of state who would be assisted by an advisory (shura) council.

Mawdudi's objections inspired other Islamist thinkers, in particular the Egyptian Sayyid Qutb whose life and works later inspired contemporary jihadists, including Zawahiri. Battle lines were drawn between those whose vision of Pakistan was for a homeland for India's Muslims that would protect them against Hindu domination and advocates of an Islamic state government by sharia. ${ }^{27}$ Muhammad Al Jinnah, Pakistan's founding father, was strongly opposed to any notions of what he termed a 'theocratic state ruled by priests with a divine mission. ${ }^{28}$ Mawdudi, meanwhile, retorted: 'if a secular and Godless instead of Islamic Constitution was to be introduced and if the British Criminal Procedure Code had to be enforced instead of the Islamic Sharia what was the sense in all this struggle for a separate Muslim Homeland? ${ }^{29}$ These tensions have never been resolved in Pakistani society where repeated attempts at constitutional reform - from the Objectives Resolution of March 1949 onwards - have resulted in awkward compromises between religious and 'manmade' legal codes where, ultimately, legal pluralism prevails. ${ }^{30}$ 
Zawahiri has spoken and written extensively about fundamental law in the country that became the Al-Qaeda leadership's adopted home after the collapse of Taliban rule in Afghanistan. In 2008, for instance, he published a four-part essay dedicated to the topic where he sought to dismiss notions that 'the Constitution of Pakistan has been erected upon a sound Islamic foundation.' Zawahiri offered an attractively simple argument: the root cause of the various problems that Pakistan was facing and the issues that many Pakistanis had complained about, such as subservience to the US and entrenched corruption, were due to the fact that Islamic principles were ignored and, for all practical purposes, absent from the Constitution. Notably, the thrust of Zawahiri's critique revolved around dissecting SGCs in the Pakistani Constitution and references to the role of Islam, focusing on the Preamble and Articles 2, 2A, 31, 38, 203 (A-J) pertaining to the Federal Shariat Court (FSC) and Part IX (Islamic Provisions). All these clauses, according to Zawahiri, were 'incapable of bringing about the establishment of the Sharīah, both in theory and in practice'. ${ }^{31}$ The Constitution, he complained, legalised fasiq, disobedience to the sharia, which in itself constituted an act of infidelity, kufr. For example, the President, who could be a woman according to the Constitution (Article 41), was given authority to pardon any crime (Article 45), regardless of severity and mandatory sharia punishment that might apply, whilst politicians could not themselves be charged with breaching sharia (Articles 48, 66, 248). ${ }^{32}$ The implication of Zawahiri's thesis of course was that the Pakistani state was illegitimate and could thus be justly targeted in acts of violence since its architects of fundamental law 'had received training within the English culture and were in awe of their civilization. ${ }^{, 33}$

Yet more attempts at societal construction in the Muslim world have presented new and unexpected ideological challenges to Zawahiri's preferred interpretation of doctrine.

\section{Sharia references and a jihadi war of words}

The emergence of ISIL-which in contrast to Zawahiri began to implement its interpretation of scripture on the ground after consolidating territory-has forced the latter to formulate a public relations response, which defines Al-Qaeda's model of jihad as more sustainable and legitimate. The ensuing war of words between ISIL and 
Zawahiri, which centres on accusations and counteraccusations of sharia infringement, helps us to position the latter in this regard within a broader milieu of jihadi actors with a stake in politics and society in the Middle East and beyond.

Zawahiri has charged ISIL of breaking the code of fealty not only to the AlQaeda leadership but ultimately to the Afghan 'Islamic Emirate' led by the Taliban. Zawahiri accuses ISIL of being excessive in its violence and unjust in its sectarian targeting, as well as undermining the greater struggle against America and its allies. ISIL's violence is presented as being counterproductive and extra-legal, particularly as regards Muslim victims of violence, and the result of arrogant leadership that risks fomenting turmoil in the region. ${ }^{34}$

ISIL representatives, in turn, have retorted by challenging Zawahiri's leadership, focusing in particular on his apparent dereliction of sharia. ISIL has made explicit references to sharia in its public relations output to justify its violence against Sinjar Yazidis and enslavement of those who survived and highlighted examples of huduud — sharia punishment — in cities it has controlled for 'offences' such as sodomy and consumption of pornography. ${ }^{35}$

With respect to Zawahiri and Al-Qaeda, ISIL spokespersons have presented the former's apparently 'relaxed' approach towards sectarianism, and the Shia laity especially, as a form of sharia violation that undermines the sanctity of the followers of the true creed. The fifth and sixth editions of ISIL's English language Dabiq magazine for example referred to Zawahiri's 2008 media initiative called the 'Open Meeting' where the Al-Qaeda leader responded to questions issued via online forums. Here, Zawahiri used the opportunity to clarify his stance towards Shia who were, he argued, 'excused due to their ignorance' and could thus not be condemned en masse. Their 'guilt', he argued, would depend on particular action such as collaborating with American occupiers. ${ }^{36}$ This stance, argues ISIL, amounts to sharia violation since takfir - excommunication - is limited to particular individuals and behaviours, not the essence of apostasy, which is the position that ISIL representatives embrace. ${ }^{37}$

In another issue of Dabiq, an ISIL loyalist recounted experiences from his time with Al-Qaeda in Waziristan where he claims non-Islamic 'tribal laws' prevailed over sharia, accusing the 'pacifist' Zawahiri of neglecting to carry out appropriate 
sharia punishment in the interest of retaining tribal alliances. ${ }^{38}$ Zawahiri, ISIL alleges, has thus 'abandoned the pure heritage' left by Usama bin Ladin. ${ }^{39}$

Zawahiri, in turn, has sought to undermine ISIL with his own references to sharia, presented in similarly static terms, in his public relations efforts. He accused Abu Bakr al-Baghdadi, the leader of ISIL who declared himself Caliph in June 2014, of contravening the example set by the prophet as described in hadith-an extremely serious accusation - especially the principles of consultation and proportionality and of rejecting arbitration of 'independent' sharia courts, proposed to resolve tensions between rival jihadist groups in Syria. 'Whoever was testified against by the established religious scholars that he escapes from being called to be arbitrated with Shariah', Zawahiri warned, 'is not on the method of Prophet-hood; he is not even suitable for an allegiance to be pledged to him., 40

If, for simplicity's sake, contemporary Salafi-jihadi praxis is divided into political-military pragmatism and ideological puritanism ${ }^{41}$, the rise of ISIL and its spat with the Al-Qaeda leadership clearly places Zawahiri, in practical terms, in the former camp in terms of the methods to achieve desired results. Whilst he has been condemned by former jihadis in Egypt for his excesses, Zawahiri comes across as a 'middle-of-the-road' jihadi next to, for example, ISIL and its followers.

Yet whilst he has shown - and been condemned for-flexibility as regards sectarian issues and aspects of doctrine, Zawahiri has dedicated his career to articulating a particular position in terms of societal construction based on the implementation of his vison of sharia and constitutional reform. This component of Zawahiri's rhetoric is often overlooked or reduced to commonly observed depictions of democracy as an idolatrous, false and alien system. Yet, as the examples from Pakistan above serve to illustrate, Zawahiri has sought to participate in debates about constitutional reform and social-legal issues in great detail which demonstrates the essence of his grievance that goes far beyond a simple protest against foreign interference. Zawahiri's preoccupation with constitutions and the laws that govern society, meanwhile, unveils a core weakness of his argument: whenever sharia implementation has been tabled as a form of constitutional reform the inevitable conclusion has been legal hybridity, a form of compromise which, in turn, becomes central to Zawahiri's problem diagnosis. Furthermore, and given the number of actors 
involved - including Islamists of all stripes - this outcome cannot be blamed on a single set of forces such as 'America' or 'colonialism' that constitute such prominent sound bites in Zawahiri's rhetoric. Nowhere is this dilemma more acute than in Zawahiri's native Egypt.

\section{The evolution of legal hybrids in Egypt}

In spring 1947, Hassan al-Banna, the founder and first General Guide of the Egyptian Muslim Brotherhood published an open letter to the Egyptian and Arab political elites. In his letter titled 'Toward the Light', al-Banna expressed his desire to 'guide the nation' towards 'the way of Islam and its principles, its rules, its culture and its civilization' rather than 'the way of the West and the outward aspects of its life, its organization and its methods.' For al-Banna the suffering and devastation brought by the Second World War illustrated the failure of the West, its political systems, leaders, conferences and 'strange ideologies.' Islam, in turn, provided hope. Al-Banna wrote: 'there is no regime in this world which can supply the forthcoming nation with what it requires in the way of institutions, principles, objectives, and judgments to the same extent as Islam can'. Al-Banna emphasised amending Egyptian law 'such that it conforms to all branches of Islamic legislation.' In terms of administrative matters, alBanna suggested that graduates from the ancient mosque-seminary Al-Azhar in Cairo would be elevated to senior positions in the military and state bureaucracy. Societal reform would also reflect the envisaged shift to legislation based on the Quran and Sunnah exclusively. Alcohol, gambling, dancing and prostitution would thus be prohibited, schools would be segregated according to gender and the state would enforce a strict form of censorship, limiting access to films and music to productions that would be deemed palatable according to Islamic norms and values. ${ }^{42}$

Al-Banna's vision, of course, was never realised. Rather, subsequent attempts to draft and re-draft fundamental law in Egypt would refer to some elements that were contained within al-Banna's roadmap as part of a compromise 'hybrid' that was far removed from the General Guide's desire for a unified, cohesive and 'pure' 'Islamic nation. ${ }^{43}$ Although Zawahiri and other ultra-conservative Salafi-jihadis condemned 
the Brotherhood for its apparent leniency and willingness to embrace democracy, they too emphasised the need for a unified state governed by Islamic principles solely rather than 'hybrids' that incorporated different legal traditions that thus diluted applied religious doctrine. This hybrid, however, has persisted in Egypt and epitomised the different forces, identities and objectives that need to be reconciled.

A year after al-Banna published his letter, the first major attempt to reIslamise aspects of the post-independence Egyptian legal system saw the Napoleonic Code replaced with a Civil Code drafted by Abd El-Razzak al-Sanhuri. Al-Sanhuri was an advocate of adapting sharia to the needs of the modern state and this was reflected in his Code. ${ }^{44}$ In this sense, as Fadel notes, 'Pre-Modern Islamic Law would have to be transformed into a body of rules consistent with the standards of contemporary legal science.' Sanhuri's Civil Code, therefore, would 'grant a modernised Pre-Modern Islamic Law a central place in Egypt's legal system. ${ }^{45}$ In seeking to reconcile Islamic law with the modern state, however, al-Sanhuri would, again, arrive at a hybridity that would fail to satisfy Islamist purists. As Fadel argues:

\begin{abstract}
Al-Sanhūrî’s proposal to create Islamic State Law, even if it was substantively Islamic, appeared to reinforce the notion that the law was an artefact of sovereign will rather than the product of the religious and discursive practices that constituted PreModern Islamic Law, and to that extent it could still be impeached as not being truly "Islamic." Indeed, one might say in criticism of al-Sanhūrī’s vision of an Islamic State Law that there is an inherent tension between the positivist legal culture of the emergent civil law system in Egypt (and by extension, to other Arab states), and the decentralized and pluralistic discursive tradition that was constitutive of Pre-Modern Islamic Law. ${ }^{46}$
\end{abstract}

This tension has arguably persisted within Egypt and spurred on the militant Islamist fringe. Whilst the Free Officers' coup in 1952 popularised anti-Western sentiments, consensus relating to role of Islam in law and society remained elusive. Gamal Abdel Nasser's notions of nationalism and pan-Arabism in particular were condemned by Islamists and have consistently been derided by Al-Qaeda and other militant Islamist groups. In 1964, two years before he was executed by the Nasser regime, Sayyid Qutb, published an essay titled Ma'alim fi al-Tariq (Milestones on the Way). Here he famously proclaimed that Egypt was again in a state of jahiliyyah, a form of religious ignorance that prevailed before the revelation of the Quran. This approach and 
terminology has remained prominent in the discourse of Islamist militants ever since. Qutb complained that the 'whole environment, people's beliefs and ideas, habits and art, rules and laws is Jahiliyyah. ${ }^{47}$ It was necessary, Qutb argued, to 'revive that Muslim community which is buried under the debris of the man-made traditions of several generations, and which is crushed under the weight of those false laws and customs which are not even remotely related to the Islamic teachings, and which, in spite of all this, calls itself the "world of Islam." ${ }^{48}$ Law and society in Egypt had to be based entirely on the concept of tawheed, that there was only one god and authority, from which all institutions and legal structures ought to be derived. Sharia was universal law, the edict that governed all aspects of human life. Like other Islamists ideologues, Qutb presented his argument as a strict dichotomy:

Islam knows only two kinds of societies, the Islamic and the jahili. The Islamic society is that which follows Islam in belief and ways of worship, in law and organization, in morals and manners. The jahili society is that which does not follow Islam and in which neither the Islamic belief and concepts, nor Islamic values or standards, Islamic laws and regulations, or Islamic morals and manners are cared for. $^{49}$

As with al-Banna, the reality of Egypt's muddled legal hybrids was, of course, far removed from Qutb's ideal type.

This was particularly evident in Nasser's secular, authoritarian and nationalist Egypt. By the 1970's, however, the Egyptian government under Anwar Sadat found itself in a crisis of legitimacy. ${ }^{50}$ The regime had failed to attract investment and faced a stagnant economy and a growing Islamist resurgence. ${ }^{51}$ In order to shore up support from the liberal opposition and increase confidence in the economy, the Sadat regime resolved to draft a new constitution. The most important decision was to establish a new Supreme Constitutional Court (SCC) as an independent entity to oversee constitutional review. ${ }^{52}$ In an effort to placate conservative Islamists in Egypt, this constitution was later amended to reference sharia as the chief source of legislation. ${ }^{53}$ Article 2 thus stipulated: 'Islam is the Religion of the State. Arabic is its official language, and the principal source of legislation is Islamic Jurisprudence (Sharia). ${ }^{, 54}$ As Lombardi notes, although Article 2 'was not without its ambiguities, most understood it to be an SGC. ${ }^{55}$ Tasked with interpreting this clause, the SCC dealt with several significant Islamist challenges to Egyptian law, which were sometimes 
rejected and sometimes upheld. The Court, Lombardi argues, 'used a method that was heavily indebted to liberal modernism, but that also made some gestures towards more conservative methods of interpretation. ${ }^{56}$ The very interpretation of Article 2, therefore, appeared to conform to the spirit of the Constitution itself that incorporated conservative Islamic and modern liberal sources of identity.

Hassan al-Banna wrote in his aforementioned letter from 1947, 'The most dangerous period in the life of a nation, and the most deserving of critical study, is the period of transition from one situation to another. It is then that plans for the new period are laid and its guiding principles and policies are drawn up, according to which, the nation will be formed and to which it will adhere.' Although describing the process of decolonisation in Egypt, his words seem equally apt for the turmoil of the 2011 revolution and its aftermath.

After winning the elections, the Muslim Brotherhood government quickly became embroiled in bitter disputes with other factions of society and, especially, the judiciary over fundamentals of the post-authoritarian Egyptian state. Despite opposition, Mohammed Morsi and his government pressed on with the drafting of a new constitution, which was eventually approved in December 2012. The process, however, had been hugely controversial, particularly as regards the role of sharia in the Egyptian legal system. ${ }^{57}$ While Article 2 was retained, new additions were designed to strengthen the position of Islamic law in Egyptian society. Article 4 elevated the role of Al-Azhar and called for its Committee of Senior Scholars to be consulted on matters concerning Islamic law. A new clause, Article 219 was added in order to codify a particular Islamist interpretation of Article 2. This Article decreed that '[t]he "principles of Islamic law" include its universal textual proofs, its rules of theoretical and practical jurisprudence, and its material sources as understood by the legal schools constituting Sunni Islam. ${ }^{58}$ Article 219 was in essence the culmination of protracted wrangling over the wording of Article 2 and was intended to define 'the principles of sharia principles. ${ }^{59}$

Article 219 thus offered further (if ambiguous) assurances relating to the Islamic foundations of Egypt's constitution. The combination of Articles 4 and 219, moreover, caused some to be concerned that Sunni legal doctrine was being incorporated wholesale into the system of positive laws with further interpretive 
powers granted to the Al-Azhar. ${ }^{60}$ The impact of these amendments as they stood in the 2012 Constitution, of course, was never realised since the process was interrupted by the July 2013 coup. Nevertheless, even with the added emphasis on sharia and Sunni legal tradition in the 2012 Constitution, the hybrid nature of the Egyptian legal system was retained. As Fadel argues:

Whatever else one might say about the 2012 Constitution, it accurately reflects the hybrid nature of Egypt's political and legal regime over the last 150 years: continuity with Islamic legal and religious traditions, while at the same time embracing as national goals modernization in the fields of the organization of the state, economic development, and a qualified acceptance of the post-World War II regime of international human rights law. ${ }^{61}$

Even when Islamists finally did reach positions of political power in Egypt, therefore, the outcome of resulting reforms and constitutional amendments retained the spirit of legal hybridity, even if the balance shifted towards Islamic legal norms. It is the nature of awkward compromises, of course, that many groups are left frustrated and disillusioned. Some facets of the Islamist community and the Brotherhood wanted stronger references to sharia and a break from the tradition of SCC's novel, and often liberal, legal interpretations. Some Salafis clashed with other Islamists over juristic interpretations and the weight of traditional legal norms and scripture. A small faction within this Salafi milieu, moreover, has resorted to acts of violence that are justified with reference to the apparent need to 'recreate' the socio-legal realities that prevailed during first three generations of Muslims. These elements, which had always warned against the apparent fallacy of democracy, were reinvigorated in Abdel Fattah elSisi's Egypt in light of efforts to ban Islamist political groupings. Among the many voices vying for attention during these tumultuous events, moreover, Zawahiri has sought to speak to his supporters and potential sympathisers by offering a detailed dissection of constitutional issues in Egypt as part of his public relations initiative. These references form a prominent and distinct part of his public engagements that yet have largely been overlooked in the analytical literature.

\section{Zawahiri and constitutional reform in Egypt}


Despite embracing transnational jihad via Al-Qaeda, Zawahiri has always remained preoccupied with his native Egypt and occasionally issued lengthy statements and publications complaining about developments in Egypt, including the state of sociolegal and constitutional matters. There was something fundamentally wrong, Zawahiri argued, with a constitution that gave legislative power to a People's Assembly ${ }^{62}$ - the foundations of positive law_rather than implementing God's law via a religiously sanctioned process of consultation (shura). 'Either we govern according to God's revelation,' Zawahiri argued, 'making our actions agree with our words ("there is no God but Allah"), or we govern in spite of God's revelation, which means associating other gods with God, because sovereignty is God's alone. ${ }^{63}$

Constitutional issues have thus been at the heart of Zawahiri's 'grievance' narrative and a core component of his activist stance. In 1999, for instance, Zawahiri published an article on a Mohammed al-Maqdisi's 'Minbar al-Tawhid wa'l-Jihad' website titled 'Muslim Egypt between the Whips of the Torturers and the Administration of Traitors.' Here, Zawahiri identified four main categories where he felt the Egyptian regime had committed 'crimes' against Islam. The first concerned constitutional matters. A constitution that prevented uptake of the sharia and representing Western-primarily British—legal norms had not only been established, but also become deeply embedded in the Egyptian system. The other problem areas that Zawahiri identified: foreign affairs, domestic issues and educational matters, all stemmed from the fact that secularists ruled Egypt. ${ }^{64}$ As with bin Ladin's Saudifocused 'open letters' referred to above, therefore, the fundamental problem was an inherently illegitimate man-made legal structure, which — in turn - spread corruption and weakness in other spheres of society.

During the 'Arab Spring' revolutions, Zawahiri released a statement where these sentiments were reiterated. He argued: 'The Egyptian Government, as stated in its principle documents, is a nationalistic, secular, democratic government,' ruling by 'hukum al-jahiliyyah', judgments based on religious ignorance. He presented stark alternatives between the old order that was being toppled with the revolution and his vision of what ought to take its place. First, the old Egyptian government had been secular, whereas an Islamic government would abide by the heavenly creed. Second, 
although authoritarian in practice, the old regime had claimed to be democratic and adopted a democratic constitution, which respected the wishes of the masses regardless of the Islamic moral code. An Islamic government, in turn, would rely on shura, consultation, which would refer to the sharia whilst keeping the rulers accountable. Third, despite written references to popular participation, the Egyptian government had in reality been a suppressive and brutal regime that rigged elections and suppressed opposition. An Islamic government, according to Zawahiri, would, via shura, rely on spreading justice and confronting oppression, enjoining good and forbidding evil. Fourth, the old regime had relied on nationalistic sentiments and sources of identity and old colonial conceptions of state boundaries and practices, whereas the envisaged Islamic government would be based on principles of Muslim equality and unity under the auspices of a Caliphate. ${ }^{65}$

The statement, and others like it, was not intended as a detailed roadmap. Zawahiri, as noted, is a physician, not an Islamic scholar, and the references to the desired way forward have always been vague in Al-Qaeda's rhetoric. They serve the purpose of inspiring and legitimising violent activism, rather than providing details of suggested alternatives. This justificatory narrative, however, has frequently focused on problems of existing societies and sought to refute measures that might undermine Al-Qaeda's vision. In this regard, Islamist alternatives that are still far removed from Al-Qaeda's extremist rhetoric pose particular challenges as they appeal to some of the same support base (i.e. mobilised Islamists) and offer more realistic and less radical and selective interpretations of religious doctrine.

In this sense, undermining the credibility of those who might offer alternative interpretations of religious doctrine is particularly important. In the case of Egypt, the role of Al-Azhar was especially prominent. As early as 1995, bin Ladin cautioned against some the shaykhs of Al-Azhar. They had agreed to shore up the legitimacy of the Nasser regime, despite its rejection of Islamic principles in favour of nationalism and socialism, he argued. ${ }^{66}$

Much later, during the height of the Arab Spring revolutions, Zawahiri issued several statements warning against 'elements' of Al-Azhar, even as the Muslim Brotherhood was exploring ways in which to elevate the position of the mosqueseminary in the new Constitution. Al-Azhar had turned into a 'government agency' 
under the Mubarak regime, Zawahiri argued, and thus suffered from a legitimacy deficit. Its ability to operate freely had been undermined by the fact that Al-Azhar's senior leadership depended on the government's seal of approval. This was particularly the case, Zawahiri argued, with Muhammad Sayyid Tantawy, who served as Grand Imam of Al-Azhar from 1996 to $2010{ }^{67}$ Al-Azhar, according to Zawahiri, had to be able to select its own leadership regardless of outside influence ${ }^{68}$ if it was to avoid turning into 'trumpets of the government. ${ }^{69}$ Even within the confines of AlAzhar itself, however, Zawahiri warned that the institution had a 'bright side' and a 'dark side'. The former, according to the Al-Qaeda leader, represented the 'lions of Al-Azhar,' jihadis such as Abdullah Azzam-bin Ladin's mentor and one of the leaders of the Arab jihadists fighting Soviet forces in Afghanistan — and Omar Abdur Rehman-leader of the Egyptian terrorist group Al-Gama'a al-Islamiyya. ${ }^{70}$ The 'dark side', in turn, consisted of the lackeys; scholars and religious figures who were prepared to support 'secular' governments. Examples included Tantawy and several senior Afghan religious figures who opposed the Taliban. ${ }^{71}$

What about existing guarantees to safeguard and implement Islamic legal codes in Egypt? Zawahiri, in particular, has always been dismissive of the apparent utility of SGCs in the Egyptian constitution and the feasibility of introducing sharia under existing law. Article 2, Zawahiri complained, offered only vague assurances of respecting the 'principles' of sharia, without excluding man-made laws. ${ }^{72}$ As a result, any references to Islamic law were cosmetic, he argued, and designed to placate opponents of Western legal traditions. Indeed, other clauses besides Article 2, rendered these references void. For example, references to the role of the President of the Republic (such as Article 134) prohibited non-Egyptian Muslims from being elected president but did not stipulate that the candidate must be 'a Muslim, male or legitimately capable, and this is clear and absolute contradiction with the Islamic sharia,' Zawahiri insisted. Christians, Jews and even atheists could thus rise to become Head of State in Egypt or be appointed to the judiciary, whilst Sudanese, Libyan or Palestinian Muslims could not even participate in the elections, since they lived outside the borders drafted by the secret 1916 Sykes-Picot agreement between the French and British. This fundamental error had been retained in the 2012 version of the text, according to the Al-Qaeda leader. The Egyptian Constitution, according to 
Zawahiri, thus represented a clear violation of sharia as well as the entrenchment of a colonial legacy. ${ }^{73}$

In a mock 'interview' with Al-Qaeda's media arm As-Sahab published in April 2014, Zawahiri spoke in great detail about the constitutional issues that he felt continued to plague Egypt. Here he elaborated his objections concerning Article 2.

The Article, Zawahiri argued, contained two major contradictions that rendered the clause useless and, by extension, efforts to introduce or adhere to sharia in Egypt void. First, it prevented actual application of (Zawahiri's interpretation of) sharia because it spoke only of sharia principles, not the wholesale enacting of sharia and would thus allow for decisions to be legal even though they contravened Islamic law. The defunct Article 219 — of which Nour Party founder Yasser Brhami had been so proud - changed nothing, Zawahiri argued. Second, Article 2 only referred to sharia as the main source for legislation, but —as Zawahiri noted-'being the main source for legislation [...] means that it permits for the existence of sources other than the main ones. ${ }^{74}$

Furthermore, Zawahiri protested that the SCC had 'made rulings which clash violently and clearly with Islam'_-including a ruling from 1993 which argued that Article 2 did not apply retrospectively, thus greatly undermining the apparent adherence to sharia principles since laws that preceded it would still be enforceable even though they contravened Islamic law. The SCC, moreover, took its legitimacy from the wishes of the majority, not sharia, and could therefore technically repeal Article 2 completely and put the decision to a referendum, elevating 'people power' over God's law and sovereignty. Article 2 and its references to sharia, therefore did not 'govern' society but could in turn be controlled.

Numerous articles of the 2014 Constitution also contradicted it and sharia, according to Zawahiri. Article 11, for example, stipulated men and women should be equal, Article 93 obliged the state to respect treaties and conventions on human rights and Articles 65 and 67 guaranteed freedom of thought and opinion without restriction, irrespective of whether these were in violation of sharia, as Zawahiri saw it. 
Article 2, therefore, was fundamentally flawed in Zawahiri's view since it failed to protect against sharia violations elsewhere in the Constitution and in Egyptian society.

Amid the turmoil of the Arab Spring and its aftermath, and following the 2013 coup, Zawahiri issued several statements suggesting fundamental changes to the Egyptian Constitution that would remedy the flaws that he had identified. Article 2 had to be amended, he insisted, to ensure that all legislation stemmed from sharia law. ${ }^{75}$ In fact, the first act of amending the Constitution ought to be replacing the text of Article 2 with the clause: 'Islamic sharia is the sole source of legislation, and all the articles of the constitution and the law which opposed it are null and void. ${ }^{76}$ All caveats and ambiguities would thus be removed. Similar efforts had to be put in place to restructure the judiciary in order to respect and implement religious law.

With the military coup of July 2013 and subsequent efforts of the Abdel Fattah el-Sisi's government to subdue the Muslim Brotherhood, Egypt has entered a new political period. As part of this process, a new Constitution replaced the Brotherhoodsponsored 2012 version after a referendum in January 2014. In the new version, Article 219 was removed, as were provisions regarding the consultative role of AlAzhar and religious political parties were banned. The 2014 Constitution, moreover, made gender equality more explicit, as noted. Although none of the Islamist provisions of the 2012 Constitution would have satisfied the extremist militant fringe, therefore, the new Egyptian Constitution has reinforced Salafi-jihadi notions of the futility of compromise and conventional political participation. ${ }^{77}$

Within this discourse, and for Zawahiri in particular, the focus and substance of the criticism has been on 'hybrid' legal systems that combine Islamic and nonIslamic sources and on references to 'partial' recognition of Islamic law that is 'diluted' both on paper through the drafting of written constitutions with references to SGCs and in practice through the actions and decisions of the executive and judiciary.

\section{Conclusions}


Many Muslim-majority societies have grappled with the introduction of Islamic norms in their fundamental laws. For many, divergent identities and the need for compromise produce legal hybrids that mix references to Islamic law with positive law and remnants of colonial law. For Zawahiri and other Salafi jihadists such hybrids represent a fundamental sin. Religious doctrine, which cannot by definition be divided or diluted, is implemented selectively or sometimes only rhetorically. This is not only a major grievance for Zawahiri but also one that combines animosity towards tangible victimisation, such as the legacy of colonialism, with more normative and value-based assumptions of how society ought to be organised. Whilst the 'extremist ideas' espoused by terrorist leaders may be repetitive and simplistic, therefore, they can also be more multifaceted than an initial cursory glance at such discourse might suggest. Zawahiri is by no means unique in weaving multiple threads together into a grievance narrative that spans different layers of social, normative and political perspectives.

For Zawahiri, dilution of sharia is seen as a direct causal factor for other more immediately tangible grievances, such as the practice of usury, unhindered freedom of expression, nationalism, secularism, pluralism and subservience to the West. This is a holistic narrative intended for global audiences. At the same time, however, the preoccupation with constitutional reform makes it much harder to attach blame in a consistent or clear manner, given the number of different actors involved in these processes. Indeed, the preoccupation with constitutional reform, as set out in Zawahiri's discourse, highlights the tension between his rhetoric and the reality on the ground. But this tension can only be understood and documented when the substance of these public relations initiatives are compared and contrasted against the evolving political landscape in Egypt, Pakistan and other regions that formed the thrust of Zawahiri's argument.

Part of Zawahiri's narrative, therefore, can best be described as a form of radical Islamist populism where constitutional and socio-legal grievances form a perpetual loop. Simple and impracticable answers are offered to complex socio-legal challenges that can only be realistically and lastingly resolved via a process of compromise. The results of such compromises, in turn, are fed into the grievance narrative again in order to justify and promote platforms that rationalise violence against societies that are presented as being inherently illegitimate. Compromise and negotiation, therefore, is not only seen as a weakness in its own right but also a source 
of grievance, because it dilutes non-negotiable religious precepts, thus corrupting and undermining the fundamental belief system. These grievances, in turn, serve to legitimise yet more confrontation with those who seek compromise.

These grievances over the dilution of religion and its application in practice through compromise with secular regimes form part of the wider Salafi-jihadi milieu. This milieu is diverse, and reflects the heterogeneity of the organisations that form it. But a common theme that transcends organisational or ideational boundaries is a determination to reach out to and mobilise perceived constituents, to secure their support and sympathy. The challenge, in the construction and delivery of these communicative efforts, is to ensure that the substance of the message conforms to the reality faced by the message's intended audience. It must resonate in order to be effective. ${ }^{78}$ Whilst much of this message, for organisations like ISIL and Al-Qaeda, focuses on the day-to-day suffering or the aspirations of people, another thread inevitably concerns more long-term perspectives on societal organisation and political alternatives to the status quo. It is with these latter concerns, as this article has explored, that cracks emerge in the narrative endeavour of bridging political rhetoric and reality.

\section{Funding}

This research received no specific grant from any funding agency in the public, commercial or not-for-profit sectors.

\section{Author biography}

The author is a Lecturer at the Department of Politics, Philosophy and Religion, University of Lancaster and formerly Senior Research Fellow at the Centre for the Study of Terrorism and Political Violence, University of St Andrews. Recent publications include the monograph The Al-Qaeda Doctrine: The Framing and Evolution of the Leadership's Public Discourse (Bloomsbury, 2014, 2016). 
1 Robert D. Benford and David A. Snow, 'Framing Processes and Social Movements: An Overview and Assessment', Annual Review of Sociology, 26, 2000, pp. 611-639.

2 Montasser al-Zayyat, The Road to Al-Qaeda: The Story of Bin Laden's Right-Hand Man, Pluto Press, 2004: Chapter 1, pp. 15-29.

3 Halverson, Goodall and Corman define a master narrative as 'a transhistorical narrative that is deeply embedded in a particular culture', Jeffry R. Halverson, H.L. Goodall, Jr. and Steven R. Corman, Master Narratives of Islamist Extremism, Palgrave Macmillan, New York, 2013, p. 24.

4 John L. Esposito (ed.) The Oxford Dictionary of Islam, Oxford University Press, Oxford, 2003, e-book.

5 Clark B. Lombardi, 'Designing Islamic constitutions: Past trends and options for a democratic future', International Journal of Constitutional Law, 11(3), 2013, pp. 615-645, p. 617.

6 Chibli Mallat, Introduction to Middle Eastern Law, Oxford University Press, Oxford, page 33.

7 John L. Esposito (ed.) The Oxford Dictionary of Islam.

8 Ayman al-Zawahiri, 'The Islamic Spring' part 1, As-Sahab (online via YouTube 9 September 2015) since removed.

9 Joas Wagemakers, A Quietist Jihadi: The Ideology and Influence of Abu Muhammad al-Maqdisi, Cambridge University Press, Cambridge, 2012: 734 (ebook).

10 Thomas Hegghammer, 'Jihadi-Salafis or Revolutionaries? On Religion and Politics in the Study of Militant Islamism', in Roel Meijer. (ed.) Global Salafism: Islam's New Religious Movement, Hurst, London, 2009: 256-257, 264.

11 To borrow Prime Minister David Cameron's phrase, 'Isil poses a direct and deadly threat to Britain', The Daily Telegraph (August 16, 2015), http://www.telegraph.co.uk/news/worldnews/middleeast/iraq/11038121/DavidCameron-Isil-poses-a-direct-and-deadly-threat-to-Britain.html [as of January 2016].

12 Ayman al-Zawahiri, 'Reality between Pain and Hope: As-Sahab's seventh interview with Ayman Al-Zawahiri' As-Sahab, 18 April 2014.

13 Usama bin Ladin, 'The Bosnia Tragedy and the Deception of the Servant of the Two Mosques,' open letter dated 11 August 1995 (West Point: Harmony database, Combating Terrorism Center), AFGP-2002-003345.

${ }^{14}$ Usama bin Ladin, 'Open Letter for Shaykh Bin Baz on the Invalidity of His Fatwa on Peace with the Jews', open letter date 29 December 1995 (West Point: Harmony database, Combating Terrorism Center), AFGP-2002-003345; Usama bin Ladin, 'Saudi Arabia Continues its War against Islam and its Scholars,' open letter dated 9 March 1995 (West Point: Harmony database, Combating Terrorism Center), AFGP-2002-003345.

15 Roel Meijer, 'Yusuf Al-Uyairi and the Making of a Revolutionary Salafi Praxis' Die Welt des Islams 47, 2007, pp. 422-459

16 Mohammad Fadel, 'Judicial institutions, the legitimacy of Islamic state law and democratic transition in Egypt: Can a shift toward a common law model of adjudication improve the prospects of a successful democratic transition?' International Journal of Constitutional Law, 11(3), 2013, pp. 646-665. 
${ }_{17}^{17}$ Fadel, 'Judicial institutions', pp. 648-649.

18 Clark B. Lombardi, 'Designing Islamic constitutions: Past trends and options for a democratic future', p. 616

${ }^{19}$ Whereby 'laws that conflict with Islamic law, however that may be interpreted, are invalid'. Karen Stilt, 'Contextualizing constitutional Islam: The Malayan experience', International Journal of Constitutional Law, 13(2), 2015, p. 407.

${ }^{20}$ Lombardi, 'Designing Islamic constitutions', p. 616.

${ }^{21}$ Karen Stilt, 'Contextualizing constitutional Islam: The Malayan experience', p. 408.

22 Sujit Choudhry, 'Constitutional transitions in the Middle East: Introduction', International Journal of Constitutional Law, 11(3), 2013, pp. 611-614, p. 612.

23 Mehrdad Kia, Daily Life in the Ottoman Empire (Santa Barbara Calif: Greenwood Press, 2010). I define the term 'socio-legal' broadly for this article to refer to laws, legal reform and related debates that concern the governance and organisation of society, of which constitutions are a key part.

24 Ayman Al-Zawahiri 'The Zionist Crusader's Aggression on Gaza and Lebanon' (online: As-Sahab, 27 June 2006), since removed, trans. into English by IntelCenter, Words of Ayman al-Zawahiri Vol. 1, Alexandria: Tempest Publishing, 2006.

25 See further on the Ottoman myth in Islamist extremist discourses in Halverson, Goodall and Corman, Master Narratives of Islamist Extremism, chapter 11.

26 Ayman Al-Zawahiri, 'Message to the people of Turkey,' (online: As-Sahab, 15 August 2010), since removed

27 Andrew Wilder, 'Islam and Political Legitimacy in Pakistan' in Mohammad Syed (ed.), Islam and Democracy in Pakistan, p. 38.

28 In Wilder, 'Islam and Political Legitimacy in Pakistan', p. 38

29 In Wilder, 'Islam and Political Legitimacy in Pakistan', p. 38

30 Barends 'Shari'a in Pakistan', p. 68; E. Adamson Hoebel, 'Fundamental Cultural Postulates and Judicial Law Making in Pakistan', American Anthropologist Special Publication 67 (6), 1965, pp. 43-56.

31 Ayman Al-Zawahiri, 'The Morning and the Lamp to be Extinguished: An Analysis of the Claim that the Constitution of Pakistan is Islamic', 2008, trans. by Abu Musa Abdus-Salam, March 2010, publisher not stated, p. 47.

32 Zawahiri, 'The Morning and the Lamp to be Extinguished', 29.

33 Zawahiri, 'The Morning and the Lamp to be Extinguished', p. 74.

34 Donald Holbrook 'Al-Qaeda and the Rise of ISIS', Survival, 57:2, pp. 93-104, 2015.

${ }^{35}$ Unknown, 'Clamping Down on Sexual Deviance', in Dabiq Issue 7, published by 'Al-Hayat' media, 2015.

36 Ayman Al-Zawahiri, 'The Open Meeting with Sheikh Ayman al-Zawahiri, Part One,' answers published by As-Sahab, 2 April 2008, secured from Archive.org and Islamist web forum, transcript also available in IntelCenter, Words of Ayman alZawahiri Vol. 1, Tempest Publishing, 2008, Alexandria, VA. Zawahiri expanded upon his stance towards the killing of Muslims in some detail in his essay 'Exoneration: A Letter Exonerating the Ummah of the Pen and the Sword from the Unjust Allegation of Feebleness and Weakness' where he argued that misinterpretation of sharia had resulted in collaborators being mistakenly shielded in order to avoid shedding Muslim blood whilst some activists had failed to strike, 
again incorrectly, purely since it was difficult to distinguish between collaborator and non-collaborator, even though the former was inflicting harm on the ummah.

Abū Maysarah ash-Shāmī, 'The Qa'idah of Adh-Dawahiri, Al-Harari, and AnNadhari and the absent Yemeni Wisdom' in Dabiq (issue 6), published by 'AlHayat' media, 2015: 16-25.

38 Abū Jarīr ash-Shamālī, 'Al-Qa'idah of Waziristan: A Testimony from Within', in Dabiq, issue 6, 2015: 40-55.

39 Unknown, 'Responding to the Doubts' in Dabiq, issue 7, 2015: 25.

40 Ayman al-Zawahiri, 'The Islamic Spring', part 3, As-Sahab (online via YouTube, 21 September 2015), since removed.

${ }^{41}$ Brynjar Lia, "Destructive Doctrinarians": Abu Mus'ab al-Suri's Critique of the Salafis in the Jihadi Current', in Roel Meijer (ed.) (pp. 281-301) Global Salafism: Islam's New Religious Movement, Hurst, 2009, London: 283.

42 Hassan Al-Banna, 'Toward the Light', 1947, $<$ http://bdislam.com/manhaj/books/Towards\%20the\%20Light.pdf $>$ (27 July 2014).

43 Al-Banna, 'Toward the Light'

${ }^{44}$ Nabil Saleh, 'Civil Codes of Arab Countries: The Sanhuri Codes' Arab Law Quarterly, 8 (2) 1993, pp. 161-167.

45 Fadel, 'Judicial institutions', p. 652.

${ }^{46}$ Fadel, 'Judicial institutions', p. 653.

47 Sayyid Qutb, Milestones, (New Delhi: Islamic Book Service), p. 8.

48 Qutb, Milestones, p. 3.

49 Qutb, Milestones, p. 49.

${ }^{50}$ Lombardi, 'Designing Islamic constitutions', p. 629.

51 Tamir Moustafa, The struggle for constitutional power: law, politics, and economic development in Egypt (Cambridge: Cambridge University Press), pp. 45 .

52 Moustafa, The struggle for constitutional power; Lombardi, 'Designing Islamic constitutions', p. 629

53 Lombardi, 'Designing Islamic constitutions', p. 629

54 Egypt's Government Services Portal, 'Egypt Constitution', 2013, $<$ http://www.egypt.gov.eg/english/laws/constitution/chp_one/part_one.aspx $>$ (23 November 2013).

55 'Egypt Constitution', 2013.

56 Lombardi, 'Designing Islamic constitutions', p. 630.

57 Fadel, 'Judicial institutions', p. 647.

58 Fadel, 'Judicial institutions', p. 647.

59 Clark Lombardi and Nathan J. Brown, 'Islam in Egypt's New Constitution', Foreign Policy, 13 December 2012, p. 3.

${ }^{60}$ Lombardi and Brown, 'Islam in Egypt's New Constitution'.

61 Fadel, 'Judicial institutions', p. 648.

62 The Constitution of the Arab Republic of Egypt, 1971 (as amended to 2007), Article 86.

63 Ayman al-Zawahiri, 'The Bitter Harvest: The Brotherhood in Sixty Years' originally published in 1991) in Gilles Kepel and Jean-pierre Milelli (eds.) Al Qaeda in its Own Words (Cambridge: Harvard University Press, 2008).

64 Ayman al-Zawahiri, 'Muslim Egypt between the Whips of the Torturers and the Administration of Traitors' (online: 'Minbar al-Tawhid wa'l-Jihad' (14 January 1999) trans. in William McCants, Jarret Brachman and Joseph Felter, Militant 
Ideology Atlas: Research Compendium (West Point: Combating Terrorism Center, 2006).

65 Ayman al-Zawahiri, 'A Message of Hope and Glad tidings to our people in Egypt (1),' (online: As-Sahab, 19 February 2011), since removed.

66 Usama bin Ladin, 'Scholars are the Prophet's Successors,' open letter dated 6 May 1995, (West Point: Harmony database, Combating Terrorism Center), AFGP2002-003345.

67 Ayman al-Zawahiri, ‘Al-Azhar: The Lion's Den: Interview with Shaykh Ayman al-Zawahiri,' (online: As-Sahab, 21 November 2008), since removed.

68 Ayman al-Zawahiri, 'A Message of Hope and Glad tidings to our people in Egypt (6),' (online: As-Sahab, 21 May 2011), since removed.

69 Ayman al-Zawahiri, 'Message of Hope and Glad Tidings to Our People in Egypt part 8: And what About the American Hostage Warren Weinstein?' (online: AsSahab, 1 December 2011), since removed.

70 Both Azzam and Rehman graduated from Al-Azhar.

71 Ayman al-Zawahiri, 'A Message of Hope and Glad tidings to our people in Egypt (6)'

72 Ayman al-Zawahiri 'The Open Meeting with Sheikh Ayman al-Zawahiri, Part Two'

73 Ayman al-Zawahiri, 'Unifying the Word toward the Word of Monotheism', (online: As-Sahab, 7 April 2013), since removed.

74 Ayman al-Zawahiri, 'Reality between Pain and Hope'.

75 Ayman al-Zawahiri, 'A Message of Hope and Glad tidings to our people in Egypt (6)'

76 Ayman al-Zawahiri, 'A Message of Hope and Glad tidings to our people in Egypt (7),' (online: As-Sahab, 21 May 2011), since removed.

77 There has been a marked upsurge in terrorist activity in Egypt after Abdel Fattah elSisi became president, especially with the emergence of Ansar Bait al-Maqdis, which joined ISIL in November 2014.

${ }^{78}$ The literature on collective action frames, for example, emphasises the need for a 'mobilising message' to match the experiences of constituents and reflect their core ideology. See Robert D. Benford and David A. Snow, 'Framing Processes and Social Movements. 